\title{
Kamila Soszyńska
}

ORICD: 0000-0002-8085-8888

Szkoła Podstawowa nr 12 w Siedlcach

\section{ROLA I ZNACZENIE NAUCZYCIELA WSPOMAGAJĄCEGO W PROCESIE TERAPII UCZNIÓW ZE SPECJALNYMI POTRZEBAMI EDUKACYJNYMI}

\author{
The role and importance of the support teacher in the therapy \\ process of students with special educational needs
}

https://doi.org/10.34739/sn.2021.21.04

\begin{abstract}
Abstrakt: Celem badań przedstawionych w niniejszej pracy było ustalenie roli i znaczenia nauczyciela wspomagającego w terapii uczniów ze specjalnymi potrzebami edukacyjnymi. Uwzględniono podstawy prawne regulujące rolę i zadania nauczycieli. W pracy jako technikę badawczą wykorzystano wywiad. Dzięki sprecyzowanym pytaniom ułożono - jako narzędzie badawcze - kwestionariusz wywiadu. Omówiono problemy odpowiadające konkretnym hipotezom. W badaniach wykorzystano metodę indywidualnych przypadków. Dokładnie porównano cechy nauczyciela wspomagającego i wiodącego w klasie integracyjnej, szczególną uwagę zwrócono również na relacje nauczycieli z rodzicami. Na podstawie wyników badań ustalono cechy pracy z uczniami o specjalnych potrzebach edukacyjnych. Wyciągnięto wnioski, które mogą być przydatne do efektywnego opracowania działań nauczyciela wspomagającego, podejmowanych przez niego w pracy z uczniami z orzeczeniem.

Słowa kluczowe: nauczyciel wiodq̨cy, nauczyciel wspomagajqcy, rodzice, system edukacji, szkoła integracyjna, uczeń ze specjalnymi potrzebami edukacyjnymi

Abstract: The purpose of the research in this paper was to establish the role and importance of a support teacher in the therapy process of students with special educational needs. The role and tasks of the teacher were taken into account on the legal basis. An interview was used as a research technique in the work. Thanks to the precise questions, the interview questionnaire was compiled as a research tool. Problems corresponding to specific hypotheses were discussed. The study used the method of individual cases. The characteristics of the support teacher and the leading teacher in the integrated class were carefully compared and special attention was also paid to the relationship between teachers and parents. Based on the rese-
\end{abstract}


arch, the characteristics of working with students with special educational needs were established. Conclusions were drawn for the effective development of the activities of the support teacher who works with students with judgment.

Keywords: leading teacher, support teacher, parents, education system, integration school, student with special educational needs

\section{Wstęp}

Pojęcie specjalnych potrzeb edukacyjnych odnosi się do uczniów, którzy nie są w stanie sprostać wymaganiom zwykłego programu edukacyjnego i - tym samym - mają znacznie większe problemy z nauką od swoich rówieśników. Dzieci te są w stanie kontynuować naukę, ale potrzebują wsparcia w postaci specjalnego programu nauczania, jak również pomocy wyspecjalizowanych nauczycieli. Należy w tym miejscu podkreślić, że współczesne rozumienie ucznia ze specjalnymi potrzebami edukacyjnymi nie jest związane wyłącznie z niepełnosprawnością, ale uwzględnia także inne źródła jego problemów, wynikające $z$ indywidualnych predyspozycji oraz sytuacji rodzinnej i społecznej. Polityka oświatowa na rzecz tych uczniów zmierza w kierunku promowania edukacji włączającej, która polega na ich integracji z pełnosprawnymi rówieśnikami w ogólnodostępnych szkołach, w których dzieci uczą się razem.

Edukacja integracyjna oraz integracja włączająca są formami kształcenia, z których coraz częściej korzystają uczniowie o specjalnych potrzebach edukacyjnych. Zgodnie z aktualnie obowiązującymi przepisami prawa w placówkach prowadzących kształcenie tych dzieci powinien być zatrudniony nauczyciel współorganizujący proces kształcenia, zwany potocznie nauczycielem wspomagającym. Do jego obowiązków należy m.in. prowadzenie - wspólnie z innymi nauczycielami - zajęć edukacyjnych, współpraca z innymi nauczycielami, specjalistami i rodzicami, pomoc innym nauczycielom w doborze odpowiednich form i metod pracy z dziećmi oraz prowadzenie zajęć odpowiadających indywidualnym potrzebom rozwojowym i edukacyjnym uczniów.

Zgodnie z prawem nauczyciel współorganizujący kształcenie ucznia z niepełnosprawnością, zwany powszechnie nauczycielem wspomagającym, powinien posiadać wykształcenie wyższe w zakresie pedagogiki specjalnej - o specjalności odpowiadającej potrzebom rozwojo- 
wym dzieci, z którymi ma pracować. Ze względu na odpowiedzialność, ważna jest również jego osobowość i kompetencje, dzięki którym będzie potrafił zastosować wiedzę w codziennych interakcjach. Za jeden z istotnych wyznaczników powodzenia edukacji integracyjnej uważane są również relacje pomiędzy nauczycielem prowadzącym a wspomagającym, które zapewniają uczniowi niezbędne wsparcie w warunkach integracji z naturalnym środowiskiem rówieśniczym. Należy podkreślić, że nauczyciel wspomagający pełni przede wszystkim rolę dydaktycznoterapeutyczną i w jej ramach realizuje szereg różnych zadań, których efekty powinny być wykorzystywane podczas wspólnego nauczania.

Celem badań było ustalenie roli i znaczenia nauczyciela wspomagającego w terapii uczniów ze specjalnymi potrzebami edukacyjnymi.

\section{Podstawy prawne funkcjonowania nauczyciela wspomagającego}

Współpraca nauczycieli w klasie jest jednym z głównych czynników przesądzających o powodzeniu edukacji uczniów ze specjalnymi potrzebami. Edukacja ta istotnie się zmieniła w ciągu ostatnich dwóch dekad, przechodząc od etapu nauczania uczniów z niepełnosprawnością przede wszystkim w szkołach specjalnych, do etapu kształcenia ich razem z pełnosprawnymi rówieśnikami, w ogólnodostępnych szkołach. Zmiana ta wymagała podjęcia szeregu kroków prawnych, organizacyjnych i metodycznych, które skutkowały nowymi warunkami pracy zarówno z całą klasą, jak i poszczególnymi uczniami o specjalnych potrzebach edukacyjnych [Zamkowska, 2017, s. 117-118.]

Obowiązujące w Polsce przepisy prawa definiują rolę pedagoga specjalnego jako osoby, która współorganizuje kształcenie specjalne, co implikuje charakter jej pracy, polegającej na współpracy z różnymi partnerami zaangażowanymi $w$ projektowanie procesu dydaktycznopedagogicznego i interwencji terapeutycznych dotyczących ucznia z niepełnosprawnością [Dz.U. 2017 poz. 1578]. Pedagog specjalny powinien zatem współpracować nie tylko z nauczycielem wiodącym, ale również z rodzicami ucznia oraz innymi specjalistami w szkole i poza nią. Ze względu na mnogość zadań ukierunkowanych na wspólny cel, można stwierdzić, że współpraca pomiędzy nauczycielem klasy, czyli wiodącym, a pedagogiem specjalnym, zwanym nauczycielem wspierającym, powin- 
na być traktowana jako kluczowa dla powodzenia edukacji włączającej [Minczakiewicz, 2016, s. 197-198.].

Aktualnie obowiązujące Rozporządzenie Ministra Edukacji Narodowej z dnia 9 sierpnia 2017 r. w sprawie warunków organizowania kształcenia, wychowania i opieki dla dzieci i młodzieży niepełnosprawnych, niedostosowanych społecznie i zagrożonych niedostosowaniem społecznym [Dz.U. 2017 poz. 1578] określa różne formy nauczania zintegrowanego, w przypadku których nauczyciel wspomagający może być zatrudniony. W przypadku ogólnodostępnych przedszkoli z oddziałem integracyjnym i przedszkoli integracyjnych oraz ogólnodostępnych szkół z oddziałem integracyjnym i szkół integracyjnych istnieje obowiązek jego zatrudnienia [Dz.U. 2017 poz. 1578, § 7.1.]

Na koniec należy podkreślić, że bez względu na rodzaj stanowiska lub kwalifikacje, w procesie kształcenia uczniów z niepełnosprawnością wymóg uwzględnienia w pracy z nimi zaleceń zawartych w orzeczeniu o potrzebie kształcenia specjalnego pozostaje bez zmian. W związku z tym głównym zadaniem nauczyciela wspomagającego jest współorganizowanie procesu kształcenia uczniów o specjalnych potrzebach edukacyjnych.

\section{Uczeń ze specjalnymi potrzebami edukacyjnymi}

Pojęcie specjalnych potrzeb edukacyjnych zostało upowszechnione w Deklaracji z Salamanki w sprawie zasad, polityk i praktyk w zakresie specjalnych potrzeb edukacyjnych, która jest respektowana również przez Polskę. Dokument ten, wraz z wytycznymi, został przyjęty w 1994 roku podczas światowej konferencji UNESCO, a jego inspiracją było uznanie konieczności pracy na rzecz szkół dostępnych dla wszystkich. Uczestnicy konferencji zwrócili uwagę na pilną potrzebę kształcenia dzieci, młodzieży i dorosłych ze specjalnymi potrzebami w ramach normalnych systemów edukacji. Wyrazili również przekonanie, że każde dziecko ma indywidualne cechy, zainteresowania, zdolności i potrzeby edukacyjne, dlatego systemy edukacyjne powinny być tak projektowane, aby uwzględniały różnorodność tych cech i potrzeb. Dzieci o specjalnych potrzebach edukacyjnych powinny mieć niewątpliwie możliwość uczęszczania do szkół ogólnodostępnych, co będzie najskuteczniejszym 
środkiem zwalczania dyskryminacji, tworzenia przyjaznych społeczności, budowania otwartego społeczeństwa i urzeczywistniania edukacji dla wszystkich [UNESCO, 1994].

Pomoc psychologiczna i pedagogiczna udzielana jest zgodnie z najnowszym rozporządzeniem wydanym w dniu 9 sierpnia 2017 roku [Dz.U. 2017 poz. 1591] w sprawie zasad organizacji i udzielania pomocy psychologiczno-pedagogicznej w publicznych przedszkolach, szkołach i placówkach. Polega ona na rozpoznawaniu indywidualnych potrzeb rozwojowych i edukacyjnych, wynikających z ograniczonych możliwości psychofizycznych, w szczególności - z niepełnosprawności, niedostosowania społecznego i zagrożenia nim, zaburzeń zachowania lub emocji, ze specyficznych trudności w uczeniu się, z deficytów kompetencji i zaburzeń językowych, chorób przewlekłych, sytuacji kryzysowych lub traumatycznych, niepowodzeń w nauce, zaniedbania środowiskowego - związanego z sytuacją bytową ucznia i jego rodziny, ze sposobu spędzania czasu wolnego i kontaktów środowiskowych oraz z trudności adaptacyjnych - związanych z różnicami kulturowymi lub zmianą środowiska szkolnego, w tym wynikających z wcześniejszego kształcenia za granicą.

Współczesne rozumienie specjalnych potrzeb edukacyjnych nie jest związane wyłącznie z niepełnosprawnością, ale uwzględnia także inne źródła problemów - wynikające z indywidualnych predyspozycji ucznia oraz jego sytuacji rodzinnej i społecznej. Termin „specjalne potrzeby edukacyjne" jest obecnie powszechnie akceptowany przez pedagogów, jednak należy podkreślić, że nie jest to termin oficjalny. Funkcjonuje on jedynie w języku potocznym lub opracowaniach naukowych, natomiast w przepisach prawnych z zakresu prawa oświatowego używa się określenia indywidualne potrzeby rozwojowe i edukacyjne [Olechowska, 2016, s. 29-30].

\section{Rola i zadania nauczyciela wspomagającego}

Skupienie się na specjalnych potrzebach ucznia pokazuje sposób myślenia o osobach z niepełnosprawnością i ich miejscu w społeczeństwie. Zgodnie z rozporządzeniem Ministra Edukacji Narodowej z dnia 9 sierpnia 2017 roku [Dz.U. 2017 poz. 1578] w placówce prowadzącej kształcenie tych dzieci powinien być zatrudniony nauczyciel współorganizujący 
proces kształcenia specjalnego, zwany potocznie nauczycielem wspomagającym.

Do jego obowiązków, wymienionych w rozporządzeniu, należy:

1. Prowadzenie - wspólnie z innymi nauczycielami - zajęć edukacyjnych oraz - wspólnie z innymi nauczycielami, specjalistami i opiekunami - grup wychowawczych; realizacja zintegrowanych działań i zajęć wskazanych w programie.

2. Prowadzenie - we współpracy z innymi nauczycielami, specjalistami i wychowawcami - pracy pedagogicznej z uczniami niepełnosprawnymi, niedostosowanymi społecznie oraz zagrożonymi niedostosowaniem społecznym.

3. Uczestniczenie, w miarę potrzeb, w zajęciach edukacyjnych prowadzonych przez innych nauczycieli, jak również w zintegrowanych działaniach i zajęciach prowadzonych, zgodnie ze wskazaniami programowymi, przez innych nauczycieli, specjalistów i wychowawców grup.

4. Pomaganie nauczycielom prowadzącym zajęcia pedagogiczne oraz nauczycielom, specjalistom i wychowawcom grup prowadzącym zintegrowane działania i zajęcia $w$ doborze form i metod pracy z uczniem niepełnosprawnym, niedostosowanym społecznie i zagrożonym niedostosowaniem społecznym.

5. Prowadzenie zajęć odpowiadających indywidualnym potrzebom rozwojowym i edukacyjnym oraz możliwościom psychofizycznym uczniów, w szczególności zajęć rewalidacyjnych, resocjalizacyjnych i socjoterapeutycznych.

Zgodnie z prawem, nauczyciel wspomagający powinien posiadać wykształcenie wyższe w zakresie pedagogiki specjalnej, o specjalności odpowiadającej potrzebom rozwojowym dzieci, z którymi ma pracować. Może to być oligofrenopedagog - pracujący z dziećmi z upośledzeniem umysłowym lub autyzmem, tyflopedagog - zajmujący się edukacją uczniów niewidomych i słabowidzących, surdopedagog - przygotowany do pracy z dziećmi niesłyszącymi i słabosłyszącymi, terapeuta pedagogiczny, logopeda czy socjoterapeuta.

Nauczyciel wspomagający pełni przede wszystkim rolę dydaktyczno-terapeutyczną, w ramach której realizuje szereg różnych zadań, 
a pierwszym z nich jest opracowywanie, modyfikowanie i ocenianie indywidualnego programu edukacyjno-terapeutycznego wraz z nauczycielem wiodącym i specjalistyczną kadrą. Kolejnym z zadań jest prowadzenie działań rewalidacyjnych, co w przypadku ucznia z autyzmem oznacza działania mające na celu rozwój umiejętności społecznych, w tym komunikacyjnych. Ich efekty powinny być wykorzystywane podczas wspólnego nauczania, a nauczyciel wiodący powinien być zaznajomiony z programem zajęć rewalidacyjnych [Włodarczyk-Dudka, 2016, s. 159-161]

Nauczyciel wspomagający pełni również rolę opiekuna i wychowawcy, w ramach której prowadzi pracę wychowawczą z uczniami z niepełnosprawnością oraz omawia - wspólnie z innymi nauczycielami i specjalistami - pojawiające się w jej trakcie problemy wychowawcze.

Kolejną z pełnionych ról jest rola promotora działań integracyjnych, która polega wspólnym - z nauczycielem wiodącym - realizowaniu takich działań, które wspierają integrację uczniów danej klasy i całej szkoły (kooperacyjny model nauczania), ułatwiają utrzymywanie między nimi pozytywnych kontaktów, kształtują właściwe postawy, prowadzą do tworzenia sieci koleżeńskiego wsparcia oraz integrowania się rodziców [Zamkowska, 2017, s. 122]

W ramach roli współorganizatora zajęć edukacyjnych oraz działań zintegrowanych o charakterze rewalidacyjnym nauczyciel wspomagający powinien brać udział w lekcjach prowadzonych przez innych nauczycieli, wspólnie z nimi opracowywać strategie prowadzenia lekcji - wskazywać na ich treści i poszerzane w ich trakcie zakresy umiejętności, ustalać kryteria i sposoby oceniania, jak również wspólnie z innymi nauczycielami prowadzić zajęcia. Elementem tej roli jest także bycie członkiem zespołu do spraw specjalnych potrzeb edukacyjnych, w skład którego wchodzi również nauczyciel wiodący, i zajmowanie się koordynację działań tego gremium [Zamkowska, 2017, s. 122].

Nauczyciel wspomagający pełni dodatkowo rolę konsultanta i doradcy wobec nauczyciela wiodącego, ale również - rodziców uczniów, udzielając im wsparcia, informując o sytuacji w klasie oraz przekazując różne porady i wskazówki. W ramach tej roli wspiera on innych nauczycieli i specjalistów w zakresie wyboru odpowiednich form i metod pracy z uczniami z niepełnosprawnością [M. Korneluk, M. Nazarczuk, 2008, 
s. 208-209] Natomiast ostatnia z pełnionych przez nauczyciela wspomagającego ról polega na byciu łącznikiem - podejmowaniu współpracy nie tylko z rodzicami, ale też licznymi instytucjami zewnętrznymi, w tym poradniami psychologiczno-pedagogicznymi i specjalistycznymi, ośrodkami doskonalenia nauczycieli, organizacjami pozarządowymi i placówkami kształcenia specjalnego. Należy podkreślić, że efekty tej współpracy są pośrednio wykorzystywane także przez nauczyciela wiodącego [Włodarczyk-Dudka, 2016, s. 161].

Zgodnie z rozporządzeniem sposób pracy nauczyciela wiodącego i wspomagającego powinien opierać się na wspólnym nauczaniu w klasach i grupach wychowawczych, uczestnictwie w zajęciach edukacyjnych oraz zajęciach i działaniach zintegrowanych określonych w programie, jak również - doborze form i metod stosowanych w pracy z uczniami o specjalnych potrzebach edukacyjnych. Należy zauważyć, że o ile kwalifikacje niezbędne na stanowisku nauczyciela w szkolnictwie specjalnym zostały jasno określone, o tyle kryteria dla kandydatów na nauczyciela zatrudnianego do pracy z uczniami ze specjalnymi potrzebami w innych typach szkół - ograniczają się do sformułowania, że na stanowisku tym można obsadzić nauczyciela pedagoga, który ukończył studia wyższe lub podyplomowe w zakresie pedagogiki o odpowiadającej prowadzonym zajęciom specjalności [Skura, 2018, s. 68]

Głównym zadaniem pedagoga specjalnego jest holistyczne spojrzenie na uczniów ze specjalnymi potrzebami edukacyjnymi, diagnoza ich problemów oraz dostosowanie programu nauczania, form i metod pracy oraz pomocy dydaktycznych - do ich możliwości psychofizycznych. Trafna i rzetelna diagnoza jest podstawą do wielospecjalistycznej oceny poziomu funkcjonowania ucznia, a następnie opracowania indywidualnego programu pedagogiczno-terapeutycznego dla każdego dziecka posiadającego orzeczenie o specjalnych potrzebach edukacyjnych. Nauczyciel wspomagający powinien zadbać o to, aby program ten uwzględniał potrzeby konkretnego ucznia, wspólne działania nauczycieli i specjalistów pracujących z uczniem, komunikację wspomagającą lub alternatywną (w przypadku uczniów z zaburzeniami mowy lub upośledzeniem językowym), formy i czas, w jakich pomoc psychologiczno-pedagogiczna udzielana jest uczniowi (w tym jej wymiar godzinowy), działania wspiera- 
jące rodziców uczniów ze specjalnymi potrzebami edukacyjnymi (informowanie rodziców o działaniach reedukacyjnych, resocjalizacyjnych i socjoterapeutycznych), formy i sposoby współpracy nauczycieli i specjalistów oraz sposoby dostosowania procesu kształcenia do potrzeb i możliwości ucznia.

Nauczyciel wspomagający jest odpowiedzialny za organizację zajęć wyrównawczych i specjalnych przypisanych do danego ucznia. Ich celem jest rozwijanie mocnych stron i zainteresowań dziecka oraz motywowanie go do samodzielnej nauki. Nauczyciel musi tak zorganizować dodatkowe zajęcia, aby odbywały się w czasie, kiedy uczeń jest skupiony i zmotywowany, a jednocześnie - nie kolidowały z nauczaniem.

Rolą pedagoga specjalnego jest indywidualna praca z każdym uczniem ze specjalnymi potrzebami edukacyjnymi, którego dyrektor powierza jego opiece. Nauczyciel powinien dostosować zadania do indywidualnych możliwości i potrzeb psychofizycznych dziecka oraz zapewnić mu odpowiednie warunki pracy, np. posadzić w pierwszym rzędzie ucznia słabowidzącego. Aby dziecko było pozytywnie zmotywowane do pracy, powinno jak najczęściej odnosić sukcesy. Nauczyciel powinien stwarzać mu taką możliwość poprzez stopniowe zwiększanie trudności zadań, wzmacnianie pożądanych zachowań i umiejętności, korygowanie negatywnych nawyków, robienie przerw w pracy oraz urozmaicanie zadań.

Kolejnym zadaniem nauczyciela jest rozwijanie umiejętności komunikacyjnych uczniów i integrowanie ich z zespołem klasowym. W przypadku dzieci, które nie mówią lub mówią niewyraźnie, można to osiągnąć poprzez wprowadzenie narzędzi, dzięki którym mają one możliwość nawiązania rozmowy z rówieśnikami. Nauczyciel wspomagający, wraz z innymi nauczycielami, powinien stwarzać uczniom niepełnosprawnym jak najwięcej okazji do kontaktów ze zdrowymi rówieśnikami.

Rola nauczyciela wspomagającego proces edukacyjny uczniów ze specjalnymi potrzebami edukacyjnymi jest nieoceniona. Jest on najbliższym towarzyszem tych dzieci, które często traktują go jak przyjaciela, dlatego ważne jest nie tylko jego wykształcenie, wiedza i doświadczenie, ale także postawa i wartości, jakimi kieruje się w życiu. Osoba pracująca z dziećmi niepełnosprawnymi powinna cechować się życzliwością oraz 
umiejętnością słuchania i patrzenia na świat oczami swoich podopiecznych. Dzięki takiemu podejściu współpraca nauczyciela z uczniem ze specjalnymi potrzebami edukacyjnymi będzie obustronnie korzystna.

\section{Czynniki warunkujące współpracę nauczyciela wspomagającego $z$ innymi pedagogami i rodzicami}

Nauczyciel wspomagający powinien pomagać nauczycielowi prowadzącemu i nauczycielowi przedmiotu w określaniu i dostosowywaniu wymagań pedagogicznych, a także metod i form pracy, do możliwości uczniów niepełnosprawnych. Sytuacja każdego ucznia powinna być omówiona indywidualnie, ponieważ każdy uczeń potrzebuje innego rodzaju wsparcia. Na początku specjaliści powinni porozumieć się między sobą w kwestii możliwych interwencji w proces nauczania.

Innym obszarem współpracy pomiędzy nauczycielami wspomagającymi a innymi jest codzienne omawianie i rozwiązywanie problemów wychowawczych i dydaktycznych, związanych z pracą z uczniami ze specjalnymi potrzebami edukacyjnymi. Dzielenie się obserwacjami, doświadczeniami i pomysłami może sprawić, że działania podejmowane wobec tych uczniów będą bardziej skuteczne. Wymiana opinii o postępach i wysiłku ucznia stanowi podstawę do wystawienia oceny końcowej.

Współpraca nauczycieli jest szczególnie ważna we wspieraniu dzieci posiadających orzeczenie o specjalnych potrzebach edukacyjnych. Nauczyciel wspomagający spędza z dzieckiem najwięcej czasu, towarzyszy mu podczas zajęć i dlatego zna jego mocne i słabe strony oraz jest świadomy trudności $w$ nauce i przeżywanych trudności społecznych. $Z$ tego względu może on dostarczyć innym nauczycielom ważnych informacji o dziecku, o sposobach motywowania go do pracy oraz jego mocnych stronach i talentach - co może być wykorzystane do wzmocnienia poczucia własnej wartości dziecka.

Nadrzędną rolą wspólnego nauczania uczniów niepełnosprawnych i ich pełnosprawnych rówieśników jest integracja i włączanie tych pierwszych w aktywne życie środowiska, w którym żyją. Praca nauczyciela rewalidacji musi być zatem tak zorganizowana, aby nie podkreślać deficytów uczniów i wspierać ich w budowaniu pozytywnych relacji z kole- 
gami z klasy. Można to zrobić tylko wtedy, gdy nauczyciel wspomagający i nauczyciele przedmiotu podzielą pracę na lekcji w taki sposób, aby uczniowie niepełnosprawni nie byli wyróżniani z grupy rówieśniczej.

Harmonijna współpraca nauczycieli zajmujących się uczniami ze specjalnymi potrzebami edukacyjnymi wpływa na atmosferę w klasie i ma bezpośrednie przełożenie na efekty kształcenia i wychowania. Gdy uczniowie niepełnosprawni dobrze radzą sobie w szkole, wzrasta ich pewność siebie i zacierają się granice pomiędzy nimi a ich pełnosprawnymi rówieśnikami.

Nauczyciel wspomagający jest osobą, która powinna być w stałym i regularnym kontakcie z rodzicami uczniów. Systematyczny kontakt z nimi pomaga zapewnić ciągłość i spójność interwencji terapeutycznych w szkole i w domu. Dzięki informacjom uzyskanym od rodziców, nauczyciel może zdobyć dane o dziecku, które już na początku współpracy pomogą mu uniknąć błędów (np. dowie się, jak dziecko reaguje na określone bodźce, zachowania i sytuacje). Na wczesnym etapie pracy z dzieckiem rodzice mogą również dostarczyć dodatkowych informacji w stosunku do tych zawartych w orzeczeniu o potrzebie kształcenia specjalnego.

Poprzez regularne kontakty z rodzicami uczniów niepełnosprawnych, nauczyciele budują z nimi relacje oparte na zaufaniu, co ma zasadnicze znaczenie dla obu stron. Kontakty te polegają głównie na wymianie informacji o postępach dziecka w nauce, jego zachowaniu w szkole i domu oraz sukcesach i problemach na różnych poziomach funkcjonowania. Specjalista może wskazać rodzicom działania możliwe do podjęcia w domu, aby pracować nad deficytami dziecka. Potrafi również wskazać, jak pracować z dzieckiem i prawidłowo dostosować jego środowisko, aby nauka w nim była możliwie najbardziej efektywna. Spędzając wiele godzin dziennie $z$ dzieckiem niepełnosprawnym, nauczyciel zdobywa jego zaufanie i nawiązuje z nim głęboką więź - dlatego uczniowie często zwierzają mu się i mówią, co sprawia im największe trudności w szkole i poza nią. Często nie są tak otwarci wobec rodziców z obawy, że zawiodą ich oczekiwania, a dostarczanie rodzicom takich informacji może prowadzić do lepszego zrozumienia przez nich własnych dzieci i ich potrzeb. 
Współpraca pomiędzy nauczycielami jest ważnym warunkiem skutecznej edukacji włączającej, ale nie jest ona łatwym rozwiązaniem problemów wynikających z różnych możliwości i potrzeb edukacyjnych uczniów oraz realiów środowiska edukacyjnego. Powinna być ona postrzegana jako proces, w którym partnerzy poznają się nawzajem i oceniają w celu osiągnięcia konsensusu, a także określają wypełniane role i obowiązki oraz dostosowują swoje osobowości - aby dzięki temu osiągnąć zamierzone cele. $W$ procesie tym występują zarówno czynniki ułatwiające, jak i utrudniające jego przebieg.

Kolejną kwestią jest dobrowolny wybór współpracownika. Jeśli opinie nauczycieli nie są brane pod uwagę w procesie wspólnego planowania, może to prowadzić do szkodliwych - zarówno dla nauczycieli, jak i uczniów - rezultatów, dlatego nauczyciele powinni mieć możliwość wyboru partnera. Formalnie każdy nauczyciel powinien zaakceptować nałożone na niego przez przełożonych obowiązki, które obejmują współpracę z przydzielonym do klasy nauczycielem wspomagającym. Praktyka pokazuje jednak, że odpowiednie dobranie współpracowników, uwzględniające ich opinie, może przynieść więcej korzyści w kształtowaniu współpracy [Skura, 2018, s. 124]

\section{Metodologia badań}

Celem badań było ustalenie roli i znaczenia nauczyciela wspomagającego w terapii uczniów ze specjalnymi potrzebami edukacyjnymi.

Biorąc pod uwagę, że przedmiotem badań może być wszystko to, co odnosi się do problemu badawczego, istnieje ścisły związek pomiędzy problemem a przedmiotem badań. Należy zatem zwrócić uwagę na miejsce przedmiotu badań $\mathrm{w}$ procesie badawczym, rozumianym jako specyficzny system kolejnych działań, prowadzonych przez poszczególne podmioty ukierunkowane na określony cel poznawczy. W tym miejscu należy wyraźnie zaznaczyć, że w każdym procesie badawczym musi być wyodrębniony przedmiot badań, ponieważ jego brak może wskazywać, że badacz nie wie, co bada, a zastosowane metody badawcze mogą okazać się nieodpowiednie do podjętej problematyki.

Przedmiotem badań była praca nauczyciela wspomagającego w procesie wspomagania rozwoju dziecka. 
Biorąc pod uwagę powyższe definicje, głównym problemem badawczym było ustalenie opinii rodziców dzieci ze specjalnymi potrzebami edukacyjnymi na temat tego, jaka jest rola i znaczenie nauczyciela wspomagającego $\mathrm{w}$ procesie terapii.

Z powyższego problemu głównego wynikały następujące problemy szczegółowe:

1. Jakie cechy istotne w pracy z uczniami o specjalnych potrzebach edukacyjnych powinien posiadać nauczyciel wspomagający?

2. Jakie są kluczowe aspekty wsparcia i pomocy, jakich powinien udzielać nauczyciel wspomagający uczniom o specjalnych potrzebach edukacyjnych?

3. Czym powinna się charakteryzować prawidłowa współpraca nauczyciela wspomagającego z wiodącym?

4. Jakie sugestie mogłyby poprawić współpracę nauczyciela wspomagającego z wiodącym?

Główna hipoteza badawcza sformułowana na potrzeby niniejszych badań zakładała, że w opinii rodziców dzieci ze specjalnymi potrzebami edukacyjnymi podstawową rolą nauczyciela wspomagającego jest wspieranie uczniów w jak najpełniejszym realizowaniu zaplanowanego materiału i zapewnianie im optymalnych warunków do nauki.

Poszczególnym problemom szczegółowym odpowiadały natomiast następujące hipotezy:

1. Cechami istotnymi w pracy z uczniami o specjalnych potrzebach edukacyjnych, jakie powinien posiadać nauczyciel wspomagający, są zaangażowanie, cierpliwość, umiejętności interpersonalne i otwartość na współpracę.

2. Kluczowym aspektem wsparcia i pomocy, jakich powinien udzielać nauczyciel wspomagający uczniom o specjalnych potrzebach edukacyjnych, jest ich aktywne włączanie w działania edukacyjne poprzez zauważanie i eksponowanie mocnych stron.

3. Prawidłowa współpraca nauczyciela wspomagającego z wiodącym powinna się charakteryzować udzielaniem temu drugiemu informacji i wskazówek terapeutycznych związanych ze specyfiką funkcjonowania dziecka ze specjalnymi potrzebami edukacyjnymi. 
4. W celu poprawy współpracy nauczyciela wspomagającego z wiodącym konieczna jest konsekwencja w postępowaniu wobec wszystkich dzieci i rodziców oraz współdziałanie w zadaniach edukacyjnych i terapeutycznych, polegające na angażowaniu nauczyciela wspomagającego we wszystkie aspekty pracy.

W badaniach wykorzystana została metoda indywidualnych przypadków, która w pedagogice polega na analizie jednostkowych ludzkich losów uwikłanych w określone sytuacje wychowawcze lub na analizie konkretnych zjawisk natury wychowawczej przez pryzmat biografii ludzkich, z nastawieniem na opracowanie diagnozy lub w celu podjęcia działań terapeutycznych. Definicja ta wskazuje, że metoda indywidualnych przypadków może być stosowana w badaniach nad funkcjonowaniem poszczególnych osób, działaniach terapeutycznych i diagnozowaniu zaburzeń rozwoju osób trudno poddających się normalnym oddziaływaniom wychowawczym [Bodanko, 2012, s. 177-185].

Jako technikę badawczą wykorzystano wywiad, definiowany jako rozmowa kierowana, w której uczestniczą co najmniej dwie osoby: badacz i respondent. Wywiad jest formą dialogu, umożliwiającą badającemu zdobycie informacji, pomagających mu osiągnąć postawiony cel badań. Ujmowany jest on jako proces, w trakcie którego prowadzący wywiad próbuje oddziaływać na badanego za pomocą stawianych mu pytań, dążąc $w$ ten sposób do rozwiązania problemu badawczego [Sztumski, 2005, s. 120-121].

W badaniach zastosowano wywiad skategoryzowany, który polega na posługiwaniu się dokładnie opracowanym kwestionariuszem wywiadu, składającym się z pytań tworzonych według określonych zasad, co zapewnienia jednorodność i porównywalność zdobytych dzięki niemu danych [Pilch, Bauman, 2018, s. 58]

Do przeprowadzenia badań wykorzystano narzędzie badawcze w postaci kwestionariusza wywiadu. W badaniach wykorzystano dwa specjalnie w tym celu przygotowane kwestionariusze wywiadu, odrębne dla nauczycieli i rodziców. Pierwszy z nich składał się z ośmiu pytań dotyczących pracy nauczyciela wspomagającego, natomiast drugi, zawierający również osiem pytań, dotyczył opinii rodziców na temat współpracy 
z nauczycielem wspomagającym i jego zadań w nauczaniu uczniów ze specjalnymi potrzebami edukacyjnymi.

\section{Relacje nauczyciela wspomagającego i wiodącego}

W celu poznania oczekiwań i potrzeb nauczycieli na obu rodzajach stanowisk oraz ich zapatrywań na wzajemne kontakty, przeprowadzono z nimi wywiady dotyczące takich aspektów jak: cechy obydwu tych typów nauczycieli istotne $\mathrm{w}$ pracy $\mathrm{w}$ klasie, udzielane przez nich wsparcie i pomoc, zasady dobrej współpracy pomiędzy nauczycielami w klasie integracyjnej oraz sugestie, które mogą wpłynąć na poprawę tej współpracy.

Jak pokazują wyniki, zdaniem nauczycieli wspomagających, oprócz wykształcenia ważne jest także doświadczenie w pracy z dziećmi ze specjalnymi potrzebami edukacyjnymi, a w dalszej kolejności - umiejętności interpersonalne i otwartość na współpracę z nauczycielem prowadzącym. Im wyższe wykształcenie nauczyciela, tym ważniejsze jest ich zdaniem - jego doświadczenie, ponieważ jest on w stanie lepiej przewidzieć, w jakim kierunku dziecko powinno podążać.

$Z$ drugiej strony zdaniem nauczycieli wiodących ważnymi cechami osobowymi nauczyciela wspomagającego są: umiejętność współpracy, tolerancja, przejawianie inicjatywy, spostrzegawczość, zaangażowanie, tolerancyjne zachowanie oraz uczestnictwo w procesie lekcyjnym. Nauczycielka prowadząca wyjaśniła również, że taka postawa jest ważna we wspólnej pracy, ponieważ zmienia ona swoje miejsce $w$ klasie w trakcie lekcji, dzięki czemu lepiej widzi, kto pracuje, a kto nie, i kto potrzebuje pomocy, lepiej także zna dzieci z trudnościami. Respondenci podkreślali również potrzebę budowania osobistych relacji poza szkołą, co zawsze prowadzi do lepszej współpracy w klasie.

Cecha, którą powinien posiadać nauczyciel wiodący, aby współpraca w klasie integracyjnej przebiegała w sprzyjającej atmosferze, to według nauczycieli wspomagających przede wszystkim otwartość na potrzeby dziecka ze specjalnymi potrzebami edukacyjnymi. Ich zdaniem doświadczenie i staż są w tego typu pracy mniej ważne. Swoje przekonanie tłumaczyli oni tym, że nauczyciel wspomagający ma często większe doświadczenie niż nauczyciel główny i dlatego warto go słuchać, po- 
nadto nauczyciele prowadzący powinni być odpowiedzialni za wyniki w nauce wszystkich dzieci.

Nauczyciele wiodący podkreślali, że powinni bardziej współpracować z nauczycielami wspomagającymi, być bardziej otwarci na ich pomysły, a przede wszystkim - nie stawiać się ponad nimi, ponieważ słuchanie i znajdowanie wspólnych rozwiązań ma zasadnicze znaczenie. Nauczyciele argumentowali również, że taka postawa jest ważna, ponieważ przykład powinien płynąć z góry.

Podział tematyczny odpowiedzi udzielonych przez respondentów przedstawia tabela 1.

Tabela 1. Cechy nauczycieli istotne w pracy w klasie integracyjnej

\begin{tabular}{|c|c|}
\hline Nauczyciele wspomagający & Nauczyciele wiodący \\
\hline \multicolumn{2}{|c|}{ Cechy nauczyciela wspomagającego } \\
\hline $\begin{array}{l}\text { Wykształcenie, kwalifikacje } \\
\text { Doświadczanie w pracy } \\
\text { Umiejętności interpersonalne } \\
\text { Umiejętność współpracy }\end{array}$ & $\begin{array}{l}\text { Umiejętność współpracy } \\
\text { Odpowiednie cechy osobowe } \\
\text { Otwartość na pozainstytucjonalne } \\
\text { relacje }\end{array}$ \\
\hline \multicolumn{2}{|c|}{ Cechy nauczyciela wiodącego } \\
\hline $\begin{array}{l}\text { Odpowiednie cechy osobowe } \\
\text { Odpowiedzialność za całą klasę }\end{array}$ & $\begin{array}{l}\text { Chęć do współpracy } \\
\text { Otwartość na pomysły } \\
\text { Pilnowanie relacji równoważnych }\end{array}$ \\
\hline
\end{tabular}

Źródło: opracowanie własne.

Wyniki badań pokazują, że respondenci za bardzo ważne cechy osobowe nauczyciela wspomagającego uznali: zaangażowanie, spostrzegawczość, otwartość, tolerancję i cierpliwość oraz takie umiejętności jak: umiejętność współpracy, podtrzymywania kontaktów interpersonalnych i komunikacji. Wykształcenie, kwalifikacje i doświadczenie były z kolei najważniejsze dla samych nauczycieli wspomagających. W ocenie istotnych cech osobowych nauczyciela wiodącego najważniejszą rolę odgrywały takie cechy jak: otwartość, życzliwość, partnerskie nastawienie i chęć uczenia się. Dla nauczycieli wspomagających najważniejsza była ich umiejętność współpracy oraz odpowiedzialność za całą klasę. 
Uzyskane dane pozwalają zauważyć, że opinie badanych w dużej mierze pokrywały się z zawartymi w różnych publikacjach opisami dyspozycji, jakimi powinien być obdarzony nauczyciel pracujący z dziećmi niepełnosprawnymi. Istotne wydaje się, że nauczyciele wspomagający częściej podkreślali umiejętność współpracy, natomiast nauczyciele wiodący - otwartość na współpracę.

W odpowiedzi na pytanie o sposoby, w jakie nauczyciel powinien uczestniczyć w klasie integracyjnej, najwięcej osób podkreślało znaczenie jego wiedzy związanej ze specyfiką funkcjonowania dziecka ze specjalnymi potrzebami edukacyjnymi. Według nauczycieli wiodących pomoc, jakiej powinni im udzielić nauczyciele wspomagający, powinna dotyczyć poradnictwa terapeutycznego w sytuacji niewiedzy, jak reagować w stresujących momentach przy braku doświadczenia w pracy z dziećmi o specjalnych potrzebach edukacyjnych. Jednocześnie podkreślali oni swoją umiejętność reagowania na trudne sytuacje w klasie oraz umiejętność angażowania wszystkich dzieci w działania edukacyjne i społeczne poprzez dostrzeganie i podkreślanie ich mocnych stron. Podkreślili również, że należy włączyć dzieci niepełnosprawne w to, co dzieje się w klasie, tworząc w ten sposób więzi koleżeńskie, a nie tylko pomagać im. Wsparcie nauczyciela jest również niezbędne w zakresie ograniczonych możliwości umysłowych i fizycznych uczniów i wynikającej z tego konieczności dostosowania materiałów, jak również wystawiania ocen i rozmów z rodzicami.

Nauczyciele wspomagający uważali również, że oprócz wiedzy dydaktycznej, nauczyciele wiodący posiadają umiejętności, dzięki którym praca integracyjna z dzieckiem o specjalnych potrzebach edukacyjnych jest bardziej efektywna. Ich zdaniem nauczyciele ci wnoszą przede wszystkim umiejętność postrzegania klasy integracyjnej jako zespołu.

Pytania dotyczące aspektów wzajemnego wsparcia, którego nauczyciele prowadzący i wspomagający powinni sobie udzielać, przedstawiono w tabeli 2. 
Tabela 2. Aspekty wsparcia nauczyciela wspomagającego i wiodącego

\begin{tabular}{|l|l|}
\hline \multicolumn{1}{|c|}{ Nauczyciele wspomagający } & \multicolumn{1}{c|}{ Nauczyciele wiodący } \\
\hline \multicolumn{2}{|c|}{ Najważniejsze aspekty wsparcia nauczyciela wspomagającego } \\
\hline $\begin{array}{l}\text { Eksperci odnośnie do funkcjonowa- } \\
\text { nia dzieci ze specjalnymi potrzebami } \\
\text { edukacyjnymi }\end{array}$ & $\begin{array}{l}\text { Wiedza odnośnie do funkcjonowania } \\
\text { dzieci ze specjalnymi potrzebami } \\
\text { edukacyjnymi } \\
\text { Możliwość zmiany roli na lekcji } \\
\text { Dostosowanie programu i ocen } \\
\text { Rozmowy z rodzicami } \\
\text { Skuteczne rozwiązania trudnych sy- } \\
\text { tuacji wychowawczych }\end{array}$ \\
\hline \multicolumn{2}{|c|}{ Najważniejsze aspekty wsparcia nauczyciela wiodącego } \\
\hline $\begin{array}{l}\text { Wiedza dydaktyczna } \\
\text { Zrozumienie i otwartość na potrzeby } \\
\text { dziecka ze specjalnymi potrzebami } \\
\text { edukacyjnymi }\end{array}$ & $\begin{array}{l}\text { Umiejętność angażowania wszystkich } \\
\text { dzieci, również tych ze specjalnymi } \\
\text { potrzebami edukacyjnymi } \\
\text { Postrzegane klasy jako całości }\end{array}$ \\
\hline
\end{tabular}

Źródło: opracowanie własne.

Z uzyskanych danych wynika, że wszystkie grupy respondentów uważały, iż wsparcie nauczyciela wspomagającego w klasie integracyjnej polega głównie na dzieleniu się wiedzą na temat funkcjonowania dziecka ze specjalnymi potrzebami edukacyjnymi. Nauczyciele wiodący określili obszary, w których chętnie skorzystaliby z pomocy nauczyciela wspomagającego (są to obszary dostosowania, wspólnych rozmów z rodzicami i wreszcie - nauczania w zastępstwie). Udział nauczyciela wiodącego to dbałość o zakres dydaktyczny, ale także umiejętność spojrzenia na klasę jako na całość i zwrócenie uwagi na przygotowanie lekcji z udziałem dzieci ze specjalnymi potrzebami edukacyjnymi. Respondenci dostrzegali zatem inną rolę nauczyciela wspomagającego i prowadzącego: pierwszy z nich był ekspertem w pracy z dziećmi ze specjalnymi potrzebami edukacyjnymi, drugi natomiast odpowiadał za proces edukacyjny.

Dualizm ról pedagogów pracujących w klasie zintegrowanej jest również obecny w literaturze, choć wskazuje się, że ich działania powinny być planowane wspólnie i wzajemnie się uzupełniać. Z jednej strony potwierdza to istnienie edukacji włączającej jako jednej z gałęzi pedago- 
giki specjalnej, z drugiej zaś - może tłumaczyć postrzegany brak konieczności wspólnego projektowania działań w klasie prowadzonej przez dwóch pedagogów. Być może fakt, że mają oni różne doświadczenia nauczyciel wiodący zwykle uczył w szkole ogólnodostępnej, a wspomagający był wcześniej pedagogiem specjalnym - sprawia, że pomimo wytycznych inaczej postrzegają oni efekty kształcenia i odmiennie rozumieją zasady inkluzji edukacyjnej.

Jednym z celów badania było poznanie opinii respondentów na temat tego, jakie czynniki są ich zdaniem ważne we współpracy nauczyciela wspomagającego z wiodącym. Badanie wykazało, że nauczyciele wspomagający uważają, że dobra praca zespołowa zachodzi wtedy, gdy zachowania współpracujących ze sobą nauczycieli charakteryzują się spójnością w kontaktach ze wszystkimi dziećmi i rodzicami. Respondenci wyjaśniali, że jest to bardzo ważne, ponieważ rodzice często wykorzystują sytuacje braku spójności przeciwko nauczycielom. Rozmówcy podkreślali potrzebę odpowiedniego podziału zadań, czyli tworzenia zajęć, a także wspólnego oceniania i włączania dzieci w proces nauczania. Ich zdaniem ważne jest, aby wcześniej ustalić zadania, niezbędna jest również wspólna ocena i konsultacje. Podkreślali również znaczenie zgranej pracy nauczycieli i wskazywali na potrzebę wizji zespołów pracujących w grupie integracyjnej.

Nauczyciele prowadzący podkreślali z kolei istotne znaczenie współpracy (która angażowałaby nauczyciela wspomagającego we wszystkie aspekty pracy, np. przygotowanie imprez szkolnych) dla realizacji zadań edukacyjnych i terapeutycznych. Ich zdaniem nie jest możliwa nieobecność nauczyciela wspomagającego na imprezach szkolnych, na których pojawiają się dzieci z niepełnosprawnością. Dla tej grupy respondentów ważna była głębsza relacja z nauczycielem wspomagającym - nie tylko na płaszczyźnie zawodowej - ponieważ generuje ona pomysły na bieżące lekcje.

Ustalenia dotyczące współpracy odnoszą się nie tylko do treści i formalnego aspektu zajęć lekcyjnych, ale również - w dużym stopniu do kształtowania klimatu wzajemnych relacji, który wpływa nie tylko na wzajemne stosunki partnerów, ale także atmosferę $w$ klasie. Z relacji wynika, że podział ról nastąpił już na samym początku współpracy, a jej 
zasady ustalono w oparciu o takie wartości, jak wzajemna pomoc, zrozumienie, budowanie zaufania, dyskrecja i solidarność. Uzgodniono, że obydwie strony będą dyskutować o sprawach dotyczących zarówno ucznia z zaburzeniami autystycznymi, jak i każdego innego, a wszelkie nieporozumienia i konflikty będą wyjaśniane na bieżąco. Respondenci byli otwarci na wspólną pracę, uzgadnianie zasad i podział ról.

Początkowa faza uzgadniania warunków współpracy przyniosła mieszane efekty. Nauczyciele wspomagający byli otwarci na współpracę, określili jej zasady i zakres obowiązków każdej ze stron. Podobnie nauczyciele prowadzący artykułowali swoje oczekiwania co do zakresu ról swoich partnerów. Etap przed spotkaniem był ważny dla sposobu, w jaki nauczyciele wspomagający wypełniali swoje role.

Każda z ról przypisanych nauczycielowi edukacji specjalnej ma charakter współpracy. Wynika to z jego pozycji w systemie jako osoby, która wspiera pracę dydaktyczno-wychowawczą z uczniami ze specjalnymi potrzebami edukacyjnymi, prowadzoną przez nauczycieli w klasie. Badani nauczyciele wspomagający podejmowali wszystkie role, nie tylko te związane z realizacją procesu dydaktycznego i wychowawczego w klasie, ale także te związane $z$ angażowaniem innych nauczycieli zatrudnionych w szkole oraz rozwijaniem współpracy z rodzicami czy instytucjami zewnętrznymi. Nauczyciele byli często głównymi inicjatorami tych działań. Ponadto zdarzało się, że wykraczali poza zakres swoich obowiązków, przebywając z uczniem poza klasą na zasadzie wolontariatu lub wspierając rodziców w rozwiązywaniu ich problemów życiowych.

Na pozytywny przebieg współpracy wpływało duże doświadczenie nauczyciela wspomagającego w pracy z różnymi nauczycielami prowadzącymi. Początkowo doświadczenie to miało charakter negatywny, ale pozwoliło nauczycielowi wspomagającemu określić zakres swojej roli i oczekiwania co do przebiegu współpracy. Nauczyciele wykazywali się otwartą postawą i chęcią współpracy, a nauczyciel wspomagający był również wytrwały w dążeniu do celu. Ich cele i etyka pracy były zgodne i służyły optymalnemu rozwojowi ucznia, ponadto nauczyciele wysoko oceniali swoją współpracę, poświęcając czas na wspólne planowanie, realizację i ewaluację działań. 
Sprzyjającym warunkiem było również wieloletnie doświadczenie w pracy z uczniami z problemami behawioralnymi oraz rodzicami w trudnych sytuacjach życiowych. Respondenci znali i potrafili stosować strategie radzenia sobie w sytuacjach konfliktowych oraz wykazywali determinację i wytrwałość w wykonywaniu zadań w niesprzyjających okolicznościach. Stopniowo wprowadzali ucznia do klasy, stosując metodę małych kroków, szanując pozycję nauczyciela prowadzącego i budując sieć wsparcia w relacjach z różnymi partnerami - nie tylko z nauczycielem prowadzącym, ale także z rodzicami oraz poradnią psychologicznopedagogiczną.

Jednym z głównych celów współpracy obydwu nauczycieli powinno być stworzenie przez nich optymalnych warunków - zarówno uczniom ze specjalnymi potrzebami edukacyjnymi, jak i pozostałym uczniom w klasie - dla realizacji przyjętych celów dydaktycznych i wychowawczych. Z badań wynika, że efektem harmonijnej współpracy nauczycieli było umożliwienie uczniowi z autyzmem uczęszczania do szkoły ogólnodostępnej, stworzenie mu odpowiednich warunków pedagogicznych oraz zintegrowanie go z grupą uczniów pełnosprawnych, a także kształtowanie pozytywnej postawy pedagogicznej nauczycieli i społecznej - uczniów. Z drugiej strony brak otwartości nauczyciela prowadzącego na współpracę mógł wywołać trudne przeżycia emocjonalne u ucznia, jego niechęć do uczęszczania do szkoły oraz konflikty $z$ rodzicami.

Podsumowanie cech dobrej współpracy pomiędzy nauczycielami wspomagającymi i wiodącymi w klasie integracyjnej, wymienianych przez uczestników badania, znajduje się w tabeli 3. Z wywiadów z respondentami wynika, że dobra współpraca polega dla nich na partnerstwie w zakresie praw i obowiązków, jakie mają nauczyciele w klasie integracyjnej. Nauczyciele powinni być razem obecni w trudnych sytuacjach pedagogicznych i na dodatkowych zajęciach pozalekcyjnych oraz powinni być jednakowo wynagradzani. Nauczyciele wiodący zauważyli, że przyjazne stosunki pozaszkolne są także ważne dla wspólnej pracy pedagogów. Dla nauczycieli wspomagających dużą rolę odgrywał z kolei dobór w pary. Wszyscy uznali, że w celu poprawy współpracy 
konieczne jest stworzenie ogólnych jej zasad oraz danie możliwości doskonalenia pracy - poprzez systematyczną ewaluację.

Tabela 3. Cechy współpracy nauczyciela wspomagającego i wiodącego oraz możliwości jej poprawy

\begin{tabular}{|l|l|}
\hline \multicolumn{1}{|c|}{ Nauczyciele wspomagający } & \multicolumn{1}{|c|}{ Nauczyciele wiodący } \\
\hline \multicolumn{2}{|c|}{ Cechy dobrej współpracy } \\
\hline $\begin{array}{l}\text { Konsekwencja wychowawcza } \\
\begin{array}{l}\text { Współpraca i równość w działaniach } \\
\text { Dobór par }\end{array}\end{array}$ & $\begin{array}{l}\text { Współdziałanie w zadaniach eduka- } \\
\text { cyjnych i terapeutycznych } \\
\text { Relacje głębsze niż tylko profesjonalne }\end{array}$ \\
\hline \multicolumn{2}{|c|}{ Możliwości poprawy współpracy } \\
\hline $\begin{array}{l}\text { Spotkania integracyjne } \\
\text { Relacje pozainstytucjonalne } \\
\begin{array}{l}\text { Możliwość odciążenia pracą w szkole } \\
\text { z dziećmi ze specjalnymi potrzebami } \\
\text { edukacyjnymi }\end{array}\end{array}$ & $\begin{array}{l}\text { Jasno określone obowiązki nauczyciela } \\
\text { wspomagającego } \\
\text { Ustalenie obszarów współpracy }\end{array}$ \\
\hline
\end{tabular}

Źródło: opracowanie własne.

Zdaniem respondentów tym, co utrudnia współpracę w klasie integracyjnej, jest nierówny podział zadań i brak wspólnego stanowiska w kwestiach dotyczących pracy wychowawczej. Zdaniem nauczycieli wspomagających i wiodących wszelkie skomplikowane sytuacje - metodyczne i związane z trudnymi relacjami z rodzicami - można rozwiązać, jeśli nauczyciele są partnerami i mogą na sobie polegać.

Na pytanie, co mogłoby poprawić współpracę między nauczycielami w klasie integracyjnej, nauczyciele wspomagający odpowiadali, że możliwość organizowania spotkań integracyjnych, które mogłyby pogłębić relacje pomiędzy nauczycielami. Ich zdaniem jeśli nie ma możliwości spotykania się poza szkołą, powinna istnieć możliwość zmiany partnerów, ponieważ wielu nauczycieli jest przypadkowych. Uważali także, że dobrym rozwiązaniem byłyby szkolenia i wyjazdy integracyjne, na których można odreagować stres i wszelkie napięcia związane z pracą w szkole. Spotkania integracyjne są dobrym pomysłem, ponieważ dają również możliwość komunikowania się na poziomie pozaszkolnym i spojrzenia na siebie $z$ innej perspektywy. 
Z kolei nauczyciele wiodący wskazywali na potrzebę jasnego określenia zakresu obowiązków nauczyciela wspomagającego oraz odgórnego ustalenia obszarów współpracy. Nauczyciele wyjaśniali również, że jest to ważne w ich pracy, ponieważ dzięki jasnym umowom nie powstawałyby sytuacje, że muszą coś wykonać samodzielnie, ale robiliby to wspólnie z nauczycielem wspomagającym.

\section{Współpraca nauczycieli z rodzicami}

Ważnym zadaniem w świetle wyników badań jest zorganizowanie dobrej współpracy nauczycieli z opiekunami reprezentującymi środowisko domowe ucznia. Nawiązywanie i utrzymywanie pozytywnych kontaktów pomiędzy szkołą a rodziną ucznia jest ważnym zadaniem nauczyciela. Informacje o sytuacji rodzinnej pozwalają nauczycielowi lepiej zrozumieć dziecko i w ten sposób przyczyniają się do podjęcia przez niego najbardziej odpowiednich i adekwatnych działań edukacyjnych.

Według rodziców współpraca powinna opierać się na dużym zaangażowaniu zarówno rodziców dzieci zdrowych, jak i niepełnosprawnych. Do najważniejszych form takiej współpracy należą rozmowy bezpośrednie i telefoniczne, natomiast do najmniej popularnych - prowadzenie dziennika korespondencji z rodzicami oraz wizyty domowe, które praktykował tylko jeden respondent. Regularny kontakt pomiędzy rodzicami a szkołą oznacza, że rodzice są informowani o tym, co dzieje się w szkole i jak radzi sobie ich dziecko. Można więc przyjąć, że również w przypadku współpracy pomiędzy nauczycielem wspomagającym a rodziną ucznia założenia teoretyczne znalazły potwierdzenie $w$ badaniach i były realizowane w praktyce.

Rodzice najczęściej odpowiadali, że nauczycielem wspomagającym jest nauczyciel posiadający kwalifikacje w zakresie pedagogiki specjalnej, który współorganizuje nauczanie zintegrowane, uwzględnia zalecenia zawarte w orzeczeniu, a zatem nauczyciel wspierający rozwój, edukację i sferę społeczną ucznia ze specjalnymi potrzebami edukacyjnymi. Ich zdaniem jest on nauczycielem wspierającym i pomagającym dzieciom z zaburzeniami oraz dzieciom w normie intelektualnej. Wspiera on rozwój ucznia w każdym obszarze, jak również współpracuje z innymi nauczycielami. 
Według rodziców nauczyciel wspomagający zapewnia wsparcie przede wszystkim uczniom o specjalnych potrzebach edukacyjnych, ale liczne grono uznało, że wszystkim dzieciom, a szczególnie tym, które potrzebują indywidualnego podejścia i pomocy. Z przeprowadzonych z rodzicami wywiadów wynika, że do obowiązków nauczyciela wspomagającego należy kontakt z rodzicami, dostarczanie im informacji o postępach i ogólnym rozwoju ucznia oraz uczestniczenie w lekcjach z uczniami o specjalnych potrzebach edukacyjnych. Ich zdaniem nauczyciel wspomagający wdraża działania integracyjne wobec dzieci z zaburzeniami i dzieci sprawnych, jak również współpracuje i komunikuje się ze wszystkimi nauczycielami pracującymi w placówce. Rolą nauczyciela wspomagającego jest zatem przede wszystkim uczestniczenie $w$ zajęciach z uczniem o specjalnych potrzebach edukacyjnych oraz podejmowanie działań integracyjnych wobec dzieci z zaburzeniami i w pełni sprawnych.

Z uzyskanych w wywiadach danych wynika, że obecność nauczyciela wspomagającego miała wpływ na wszystkie dzieci w klasie. Nauczyciel wspomagający pracował nad integracją uczniów niepełnosprawnych i pełnosprawnych, jak również wspierał wszystkich uczniów w trakcie lekcji, gdy pojawiały się trudności w nauce. Zdaniem rodziców nauczyciel kształtował prospołeczną postawę wobec dzieci niepełnosprawnych poprzez organizowanie wspólnych imprez klasowych i zajęć pozalekcyjnych. Rodzice uznali również, że nauczyciel podejmował działania wychowawcze na równi z prowadzącym w stosunku do całej społeczności klasowej.

Większość respondentów oceniła współpracę z nauczycielami wspomagającymi jako bardzo dobrą. Zdaniem rodziców nauczyciele byli zaangażowani w rozwój zespołu klasowego oraz inicjowali działania integrujące ten zespół. Tylko jeden z respondentów stwierdził, że nauczyciel wspomagający nie robił nic pozytywnego dla rozwoju klasy.

Większość badanych rodziców uważała, że kadra pedagogiczna była dość dobrze przygotowana do pracy z uczniami o specjalnych potrzebach edukacyjnych. Zdaniem rodziców otrzymywali oni odpowiednie wsparcie od nauczyciela wspomagającego. Najczęstszymi odpowiedziami były w tym przypadku pomoc psychologiczno-pedagogiczna, nauczanie wyrównawcze, nauczanie dydaktyczne oraz dodatkowe nauczanie 
wyrównawcze. Wyniki badań pokazały również, że zdaniem wszystkich rodziców częstotliwość spotkań z kadrą pedagogiczną była wystarczająca oraz byli oni zadowoleni ze współpracy z nauczycielem wspomagającym.

Z przeprowadzonych wywiadów wynika, że zdaniem większości rodziców metody pracy stosowane przez nauczyciela wspomagającego były odpowiednie do potrzeb ich dziecka. Według rodziców dobre relacje pomiędzy nauczycielem a uczniem prowadziły do postępów w nauce dziecka, ponieważ nauczyciel stale rozpoznawał potrzeby dziecka i stosował odpowiednie do nich metody pracy. Oznaczało to, że nauczyciel wspomagający był świadomy potrzeb dziecka i dostosowywał się do jego możliwości. Z ostatniego pytania wywiadu wynika natomiast, że wszyscy badani rodzice byli zadowoleni z pracy nauczyciela wspomagającego.

\section{Podsumowanie}

Dobra współpraca nauczycieli w klasie jest jednym z głównych czynników decydujących o powodzeniu w edukacji uczniów ze specjalnymi potrzebami. Edukacja ta w ciągu ostatnich lat ewoluowała od nauczania uczniów z niepełnosprawnością przede wszystkim w szkołach specjalnych, do kształcenia ich razem z pełnosprawnymi rówieśnikami w ogólnodostępnych szkołach. Obowiązujące w Polsce przepisy prawa definiują rolę pedagoga specjalnego jako osoby, która współorganizuje kształcenie specjalne, co implikuje jej współpracę nie tylko z nauczycielem wiodącym, ale również rodzicami ucznia oraz innymi specjalistami. Sposób pracy tego nauczyciela powinien opierać się na wspólnym - z nauczycielem wiodącym - nauczaniu, uczestnictwie w zajęciach i działaniach określonych w programie, jak również - doborze stosowanych w pracy form i metod. Nauczyciel wspomagający dostosowuje także program i wymagania do indywidualnych potrzeb oraz psychofizycznych możliwości ucznia.

Przeprowadzone badania potwierdziły sformułowaną na potrzeby pracy hipotezę badawczą. Na podstawie wywiadów ustalono bowiem, że w opinii rodziców dzieci ze specjalnymi potrzebami edukacyjnymi podstawową rolą nauczyciela wspomagającego jest wspieranie uczniów w jak najpełniejszym realizowaniu zaplanowanego materiału i zapewnianie im optymalnych warunków do nauki. 
Na podstawie badań ustalono, że istotnymi w pracy z uczniami o specjalnych potrzebach edukacyjnych cechami, jakie powinien posiadać nauczyciel wspomagający, są zaangażowanie, cierpliwość, umiejętności interpersonalne i otwartość na współpracę. Kluczowym aspektem wsparcia i pomocy, jakich powinien udzielać nauczyciel wspomagający uczniom o specjalnych potrzebach edukacyjnych, jest aktywne ich włączanie w działania edukacyjne poprzez zauważanie i eksponowanie mocnych stron. Z badań wynikało również, że prawidłowa współpraca nauczyciela wspomagającego z wiodącym powinna cechować się przekazywaniem temu drugiemu wiedzy i wskazówek terapeutycznych, związanych ze specyfiką funkcjonowania dziecka ze specjalnymi potrzebami edukacyjnymi.

Podsumowując przeprowadzone badania, należy podkreślić, że w celu poprawy współpracy nauczyciela wspomagającego z wiodącym konieczne jest konsekwentne postępowanie wobec wszystkich dzieci i rodziców oraz współdziałanie w zadaniach edukacyjnych i terapeutycznych, polegające na angażowaniu nauczyciela wspomagającego we wszystkie aspekty pracy. Podejście takie pozwoli na osiągnięcie najlepszych efektów w pracy z uczniem ze specjalnymi potrzebami edukacyjnymi, a tym samym na rozwój odpowiadający jego możliwościom.

\section{Literatura}

Bodanko A. (2012), Geneza, istota i zastosowanie praktyczne metody indywidualnych przypadków, „Nauczyciel i Szkoła”, nr 1, s. 177-185.

UNESCO (1994), Deklaracja z Salamanki oraz wytyczne dla działań w zakresie specjalnych potrzeb edukacyjnych przyjęte przez światową konferencję dotyczącą specjalnych potrzeb edukacyjnych

Korneluk M., Nazarczuk M. (2008), Zakładane i realizowane funkcje nauczyciela wspomagajqcego w klasie integracyjnej, „Student Niepełnosprawny. Szkice i Rozprawy", nr 1.

Minczakiewicz E.M. (2016), Pedagog specjalny wobec wyzwań polskiej edukacji i potrzeb uczniów specjalnej troski, [w:] J. Skibska, J. Wojciechowska, Współczesna edukacja. Wielopłaszczyznowość zadań, Wyd. Libron, Kraków, s. 197-198.

Olechowska A. (2016), Specjalne potrzeby edukacyjne, Wyd. Nauk. PWN, Warszawa. 
Pilch T., Bauman T. (2018), Zasady badań pedagogicznych, Wyd. Akademickie Żak, Warszawa.

Rada Ministrów, Strategia na rzecz osób z niepełnosprawnościami 2021-2030, Warszawa 2021.

Reforma systemu kształcenia uczniów ze specjalnymi potrzebami edukacyjnymi, Ministerstwo Edukacji Narodowej i Sportu, Warszawa 1998.

Rozporządzenie Ministra Edukacji Narodowej z dnia 17 listopada 2010 r. w sprawie zasad udzielania i organizacji pomocy psychologiczno-pedagogicznej w publicznych przedszkolach, szkołach i placówkach (Dz.U. 2010 nr 228 poz. 1487).

Rozporządzenie Ministra Edukacji Narodowej z dnia 9 sierpnia 2017 r. w sprawie warunków organizowania kształcenia, wychowania i opieki dla dzieci i młodzieży niepełnosprawnych, niedostosowanych społecznie i zagrożonych niedostosowaniem społecznym (Dz.U. 2017 poz. 1578).

Rozporządzenie Ministra Edukacji Narodowej z dnia 9 sierpnia 2017 r. w sprawie zasad organizacji i udzielania pomocy psychologiczno-pedagogicznej w publicznych przedszkolach, szkołach i placówkach (Dz.U. 2017 poz. 1591).

Skura M. (2018), Relacje nauczyciela wspomagajqcego i nauczyciela wiodacego - temat wciqż otwarty, "Niepełnosprawność. Dyskursy Pedagogiki Specjalnej”, nr 29.

Sztumski J. (2005), Wstęp do metod i technik nadań społecznych, Wyd. Śląsk, Katowice.

Uchwała nr 27 Rady Ministrów z dnia 16 lutego 2021 r. w sprawie przyjęcia dokumentu strategia na rzecz osób z niepełnosprawnościami 2021-2030 (M.P. 2021 poz. 218).

Włodarczyk-Dudka M. (2016), Pedagog specjalny w zespole specjalistów, [w:] U. Bartnikowska, Cz. Kosakowski (red.), Pedagog specjalny - dylematy roli, Wyd. Uniwersytetu Warmińsko-Mazurskiego, Olsztyn, s. 159-161.

Zamkowska A. (2017), Współpraca nauczycieli w klasie włączajqcej, „Biblioteka Współczesnej Myśli Pedagogicznej", t. 6.

Zarządzenie nr 29 Ministra Edukacji Narodowej z dnia 4 października 1993 r. w sprawie zasad organizowania opieki nad uczniami niepełnosprawnymi, ich kształcenia wogólnodostępnych i integracyjnych publicznych przedszkolach, szkołach i placówkach oraz organizacji kształcenia specjalnego (Dz.Urz. MEN $1993 \mathrm{nr} 9$ poz. 36). 